\title{
Regional anesthetic techniques for hip surgery in children with cerebral palsy
}

\author{
V.V. Evreinov ${ }^{1}$, T.A. Zhirova ${ }^{2}$
}

${ }^{1}$ Ilizarov National Medical Research Centre for Orthopaedics and Traumatology, Kurgan, Russian Federation

${ }^{2}$ V.D. Chaklin Ural Institute of Traumatology and Orthopedics, Ekaterinburg, Russian Federation

\begin{abstract}
Patients with cerebral palsy (CP) experience pain through the lifespan. The hip joint is the main source of nociceptive input. Use of nonopioid adjuvant medication and regional anesthesia for hip surgeries can be an integral part of a perioperative strategy to decrease opioid use. Regional anesthesia can be delivered efficiently and safely for pediatric orthopedic patients. Objective To compare different regional anesthetic techniques used for multi-level lower limb orthopedic surgeries in children with moderate and severe CP. Material and methods A prospective randomized comparative clinical trial enrolled $101 \mathrm{CP}$ patients who underwent unilateral multi-level lower limb surgery for spastic hip displacement or subluxation. According to a type of anesthesia used, patients were allocated into 3 groups: patients receiving prolonged epidural analgesia (PEA) and fentanyl for sedation (PEAF, $\mathrm{n}=32$ ); patients receiving PEA and benzodiazepine for sedation $(\mathrm{PEAB}, \mathrm{n}=37)$, and patients receiving a continuous femoral plus single-shot sciatic nerve block and benzodiazepines for sedation (FSNBB, $\mathrm{n}=32$ ). Hemodynamic findings, pain intensity, a need for opioids and additives (NSAIDs), the level of sedation and complication rate were evaluated. Results The use of NSAIDs (paracetamol) was significantly higher in PEAB and FSNBB groups as compared to PEAF patients with fentanyl administered, and there were no statistically significant differences in the level of pain recorded with the r-FLACC score among the study groups. There were no statistically significant differences in the level of sedation and agitation measured with the Ramsay Sedation Scale and Richmond Agitation-Sedation Scale (RASS) among the groups at early postoperative period. Apnoea as a complication was observed in a PEAF patient. Conclusion A continuous femoral plus single-shot sciatic nerve block and PEA added with NSAIDs (paracetamol) and benzodiazepines for sedation have shown the comparative effectiveness and safety for a perioperative analgesia of CP patients undergoing multi-level lower limb surgeries as compared to the use of PEA and fentanyl for sedation.
\end{abstract}

Keywords: CP, infantile age, prolonged femoral nerve analgesia, prolonged epidural analgesia, hip joint surgery

\section{INTRODUCTION}

Patients with cerebral palsy (CP) experience pain through the lifespan that can be associated with spasticity, visceral dysfunction and neuropathy $[1,2]$. Regular impulsations from different sources result in sensitization of afferent neurons, depleted brain nociceptors, decreased pain threshold and pain synchronization [3]. Cognitive distortions and emotional lability of CP patients are likely to interfere with pain perception and contribute to the neutral impulses interpreted as pain with increased vigilance being experienced by the child towards pain [2]. $90 \%$ of severely impaired children with CP have recurrent pain for at least one year with $75 \%$ having pain every week and $50 \%$ present with pain episodes lasting for more than 9 hours $[4,5]$. Pain is a disabling factor for $\mathrm{CP}$ children presenting with functional limitations and decrease in health-related quality of life $[2,5,6]$. The hip joint is the main source of nociceptive input $[7,8]$. Several population-based studies have calculated that the overall incidence of spastic hip displacement and dislocation is approximately $28 \%$ across a population of children with $\mathrm{CP}$ and is proportional to their age and gross motor function as graded by the Gross Motor Function Classification System (GMFCS) [9-12]. Use of nonopioid adjuvant medication and regional anesthesia for hip surgeries can be an integral part of a perioperative strategy to decrease opioid use. Regional anesthesia can be delivered efficiently and safely for pediatric orthopedic procedures $[13,14]$. Planning an anesthetic technique and perioperative pain regimen requires consideration of the pros and cons of central and peripheral blocks. However, debate continues over the optimal approach to anesthesia and analgesia in $\mathrm{CP}$ patients undergoing orthopaedic procedures [15-19].

Objective To compare different regional anesthetic techniques used for multi-level lower limb orthopedic surgeries in children with moderate and severe CP.

\section{MATERIAL AND METHODS}

The null hypothesis was based on the assumption that a continuous femoral plus single-shot sciatic nerve block can be equally effective and safe for pain control of $\mathrm{CP}$ patients undergoing multi-level 
lower limb surgeries against other regional anesthesia techniques.

Design A prospective randomized comparative clinical trial. Randomization was performed by generating random numbers (www.randomization. com).

Study object: children with moderate and severe $\mathrm{CP}$ (graded according to GMFCS) who underwent unilateral multilevel interventions on lower limbs for spastic hip displacement/subluxation.

The study was performed at the Federal State Budgetary Institution «Russian Ilizarov Scientific Centerfor Restorative Traumatology and Orthopaedics» from January to December 2018, received a favourable opinion from the relevant research ethics committee and conducted in accordance with ethical principles for medical research involving human subjects stated in the Declaration of Helsinki and the rules of Good Clinical Practice approved by Order No. 200n dated April 01, 2016 of the Ministry of Health of the Russian Federation On Approval of Rules for Good Clinical Practice [20]. Written informed consent was obtained from all patients or legal guardians for publication of the findings without identifying details.

Inclusion criteria were age 3 to 17 years; level III-V GMFCS motor functioning and unilateral palliative or reconstructive hip interventions combined with multilevel muscle and tendon plasty of the lower limb.

Exclusion criterion was bilateral single event reconstructive hip interventions.

The study enrolled $111 \mathrm{CP}$ patients, from them 60 males and 51 females. According to a type of perioperative anesthesia used, patients were allocated into 3 groups being comparable by major factors that can impact the outcomes (Table 1).
Patients of group I received prolonged epidural analgesia (PEA) and fentanyl for sedation at early postoperative period (PEAF, $\mathrm{n}=32$ ). Patients of group II received PEA and benzodiazepine for sedation ( $\mathrm{PEAB}, \mathrm{n}=37)$, and patients of group III received a continuous femoral plus single-shot sciatic nerve block and benzodiazepines for postoperative sedation ( $\mathrm{FSNBB}, \mathrm{n}=32$ ).

Among 111 participants, $58(52 \%)$ had cooccurring conditions of epilepsy and/or hydrocephaly. Forty from fifty eight (69\%) patients suffered from epilepsy, 14 from $58(24 \%)$ diagnosed with hydrocephaly, and 4 from 58 (7\%) presented with both conditions (Table 2). Among 40 children suffering from epilepsy, 28 (70\%) received antiepileptic drug (AED) therapy that persisted during preoperatrive and postoperative periods.

All children were operated under general inhalational anaesthesia and mechanical ventilation combined with epidural blockade in PEAF and PEAB patients and peripheral blockade in FSNBB cases (continuous femoral plus single-shot sciatic nerve block). Propofol, fentanyl, rocuronium bromide were used for induction of general anesthesia with a dose adjusted according to age and body-weight. No muscle relaxants were employed for induction with regional blocks administered during narcotic anaesthesia. Sevoflurane (Sevorane ${ }^{\circledR}$, Abbott Laboratories, UK) was used as an inhalational agent for maintenance. Fentanyl infusion consisted of the medium dose of $5.0(1.9) \mathrm{mcg} / \mathrm{kg}, 5.4$ (1.9) mcg/kg, 5.7 (2.0) mcg/kg in the groups, respectively $(\mathrm{p}>0.05)$. Tranexamic $\operatorname{acid}(15 \mathrm{mg} / \mathrm{kg}$ body weight) was used perioperatively for conservative hemostasis and 6 hours after the first administration.

Table 1

Demographic patients' characteristics

\begin{tabular}{|c|c|c|c|c|c|c|c|c|}
\hline \multirow[t]{2}{*}{ Group } & \multicolumn{2}{|c|}{ Sex* } & \multirow[t]{2}{*}{$\begin{array}{c}\text { Age } \\
\text { (years) }\end{array}$} & \multirow[t]{2}{*}{$\begin{array}{c}\text { Body weight } \\
(\mathrm{kg})\end{array}$} & \multicolumn{2}{|c|}{$\begin{array}{l}\text { Risk evaluation according to the Moscow } \\
\text { Research Society of Anaesthesiology and } \\
\text { Intensive Care system* }\end{array}$} & \multicolumn{2}{|c|}{ GMFCS level } \\
\hline & male & female & & & grade III & grade IV & III-IV & $\mathrm{V}$ \\
\hline PEAF & $\begin{array}{c}59 \% \\
(19 \text { from 32) }\end{array}$ & $\begin{array}{c}41 \% \\
(13 \text { from 32) }\end{array}$ & $8.8(3.5)$ & $22.4(8.6)$ & $\begin{array}{c}47 \% \\
(15 \text { from 32) }\end{array}$ & $\begin{array}{c}53 \% \\
\text { (17 from 32) }\end{array}$ & $\begin{array}{c}53 \% \\
\text { (17 from 32) }\end{array}$ & $\begin{array}{c}47 \% \\
(15 \text { from } 32)\end{array}$ \\
\hline PEAB & $\begin{array}{c}54 \% \\
(20 \text { from 37) }\end{array}$ & $\begin{array}{c}46 \% \\
(17 \text { from 37) }\end{array}$ & $8.4(4.0)$ & $22.5(13.9)$ & $\begin{array}{c}54 \% \\
(20 \text { from 37) }\end{array}$ & $\begin{array}{c}46 \% \\
\text { (17 from 37) }\end{array}$ & $\begin{array}{c}57 \% \\
(21 \text { from } 37)\end{array}$ & $\begin{array}{c}43 \% \\
(16 \text { from } 37)\end{array}$ \\
\hline FSNBB & $\begin{array}{c}65 \% \\
(21 \text { from 32) }\end{array}$ & $\begin{array}{c}35 \% \\
(11 \text { from 32) }\end{array}$ & $8.4(4.1)$ & $20.8(8.9)$ & $\begin{array}{c}47 \% \\
(15 \text { from 32) }\end{array}$ & $\begin{array}{c}53 \% \\
(17 \text { from 32) }\end{array}$ & $\begin{array}{c}63 \% \\
(20 \text { from } 32)\end{array}$ & $\begin{array}{c}37 \% \\
(12 \text { from } 32)\end{array}$ \\
\hline
\end{tabular}

* mean value and standard deviation (SD); $\mathrm{p}>0.05$

Table 2

Co-occurring conditions diagnosed in the patients

\begin{tabular}{|l|c|c|c|}
\hline \multicolumn{1}{|c|}{ Groups } & Epilepsy & Hydrocephaly & Epilepsy and hydrocephaly \\
\hline PEAF & $20.7 \%(12)$ & $6.9 \%(4)$ & $0 \%(0)$ \\
\hline PEAB & $25.9 \%(15)$ & $12 \%(7)$ & $5.2 \%(3)$ \\
\hline FSNBB & $22.4 \%(13)$ & $5.2 \%(3)$ & $1.7 \%(1)$ \\
\hline
\end{tabular}

$\chi^{2}$ test, $\mathrm{p}>0.05$. 
Epidural infusion of a local anesthetic (ropivacaine $0.5 \%$ ) with bolus $2 \mathrm{mg} / \mathrm{kg}$ via $\mathrm{G} 20$ catheter placed at the dermatome level corresponding to the surgical site of L3-L4 was performed furtheron with $1 / 2$ of initial volume every two hours in PEAF and PEAB groups. Ropivacaine $0.15 \%$ was infused via G20 perineural catheter placed in projection of the femoral nerve of FSNBB patients [21]. Dorso-dorsal sciatic nerve block (according to Raj) was produced intraoperatively for FSNBB patients in supine position with single injection of local anesthetic [22]. The neuromuscular blockades were monitored with a nerve stimulatoris. Total anaesthetic dose applied for the neuromuscular blockades was $2 \mathrm{mg} / \mathrm{kg} 0.15 \%$ ropivacaine with $1 / 2$ estimated volume per each nerve.

The mean intraoperative dose of ropivacaine was $0.6(0.2) \mathrm{mg} / \mathrm{kg} / \mathrm{h}$ in PEAF group, $0.7(0.2) \mathrm{mg} / \mathrm{kg} / \mathrm{h}$ in PEAB patients and $0.7(0.2) \mathrm{mg} / \mathrm{kg} / \mathrm{h}$ in FSNBB group with no statistically significant differences $(p>0.05)$. All patients were extubated on the operating table at the end of the surgical procedure and transferred to the department of anaesthesiology and intensive care unit (A\&ICU) with spontaneous breathing autonomy. Continuous wound infusion of ropivacaine $0.3 \mathrm{mg} / \mathrm{kg} / \mathrm{h}$ using an elastomeric pump was produced at early postoperative period at the A\&ICU with local anaesthetic delivered at a rate of $6.5(2.5) \mathrm{mg} / \mathrm{h}, 6.7(4.1) \mathrm{mg} / \mathrm{h}$ and $6.3(2.7) \mathrm{mg} / \mathrm{h}$ in PEAF, PEAB and FSNBB patients, respectively $(p>0.05)$. NSAID (paracetamol $15 \mathrm{mg} / \mathrm{kg}$ body weight) was administered for pain scored 5 on r-FLACC scale. Opioids were used for pain scored 5 and over. Infusion of fentanyl $0.005 \%$ at the dose of $1.5 \mathrm{mcg} / \mathrm{kg} / \mathrm{h}$ was produced for sedation of PEAF patients, and midazolam $0.5 \%$ at the dose of $0.05 \mathrm{mcg} / \mathrm{kg} / \mathrm{h}$ was administered for sedation of PEAB and FSNBB patients.

Surgical injury evaluation was based on external blood loss calculated with gravimetric method and the number of intraoperative manipulations produced in different anatomical sites. The mean intraoperative blood loss was $126.6(49.5) \mathrm{mL}$ in PEAF group, 99.4 (52.7) $\mathrm{mL}$ in PEAB patients and 115.6 (59.6) $\mathrm{mL}$ in FSNBB group with no significant differences between the groups $(p>0.05)$ and measured $7.6(2.9 \%), 5.9(3.1 \%)$ and $7.5 \%(3.8 \%)$ to the circulating blood volume, respectively $(\mathrm{p}>0.05)$. Surgical injury evaluation is presented in Table 3.

Table 3

Number of manipulations produced during a surgical session

\begin{tabular}{|c|c|c|c|}
\hline \multirow[t]{2}{*}{ Group } & \multicolumn{3}{|c|}{$\begin{array}{l}\text { Number of manipulations produced during a surgical } \\
\text { session }\end{array}$} \\
\hline & 1 & 2 to 5 & 6 to10 \\
\hline PEAF & $0 \%(0)$ & $59 \%(19)$ & $41 \%(13)$ \\
\hline PEAB & $11 \%(4)$ & $57 \%(21)$ & $32 \%(12)$ \\
\hline FSNBB & $6 \%(2)$ & $63 \%(20)$ & $31 \%(10)$ \\
\hline
\end{tabular}

Parenteral fluid therapy involved the intravenous administration of crystalloid solutions and showed no statistically significant differences between the groups. Intraoperative fluid rates were $23.7(10.0) \mathrm{mL} / \mathrm{kg} / \mathrm{h}$ in REAF patients, $27.7(9.0) \mathrm{mL} / \mathrm{kg} / \mathrm{h}$ in PEAB patients and $25.8(10.9) \mathrm{mL} / \mathrm{kg} / \mathrm{h}$ in FSNBB patients $(\mathrm{p}>0.05)$. At early postopertaive period, intravenous fluid rates were $2.1(0.6) \mathrm{mL} / \mathrm{kg} / \mathrm{h}, 2.4(0.6) \mathrm{mL} / \mathrm{kg} / \mathrm{h}$, $2.4(0.7) \mathrm{mL} / \mathrm{kg} / \mathrm{h}$ in the groups, respectively $(p>0.05)$. The patients were transported to the clinical department on the first day postsurgery. Common blood count was performed perioperatively, 6 hours postoperatively and on the first postoperative day.

The transfusion of whole blood or packed red blood cells was indicated in acute anemia caused by precipitous blood loss with a $25 \%$ decrease in circulating blood volume, hemoglobin $<80 \mathrm{~g} / \mathrm{L}$, hematocrit $<25 \%$, and/or blood circulation disorders.

Assessment criteria included standard basic hemodynamics: the mean arterial pressure (MAP), heart rate; pain intensity; a need for opioids and additives (NSAIDs), the level of sedation and agitation; depth of sedation and complication rate.

Measurements were produced perioperatively, at admission to ICU and 6 hours after admission to ICU and at 6 o'clock in the morning on the first postoperative day.

The mean arterial pressure (MAP), heart rate (HR) were measured in a non-invasive manner using anesthesia monitor at admission to the theater, after induction/tracheal intubation, after epidural injection of local anesthetic or femoral plus single-shot sciatic nerve block, at the beginning of surgery, during the major surgical phase and after tracheal extubation.

Richmond Agitation-Sedation Scale (RASS) was used to measure the agitation or sedation level of the patients. Sedation scoring was performed for sedated patients using Ramsay Sedation Scale [23].The level of pain was recorded with the r-FLACC (revised Face, Leg, Activity, Cry and Consolability) scale [24].

Statistical data analysis was performed using StatPlusPro5 computer program. All samples of quantitative data were tested to determine normality of distribution in the groups. The data obtained were summarized as means \pm standard deviations (SD) in normal distribution. Single-factor analysis of variance was used for comparisons between the groups followed by a stepwise multiple comparisons procedure using the Newman-Keuls method or Bonferroni correction. $\chi^{2}$ test was used to compare the distribution of the outcome. For calculations, a significance level $\alpha$ of $5 \%(\mathrm{p} \leq 0.05)$ was adopted with the null hypothesis rejected. 


\section{RESULTS}

No statistically significant differences in hemodynamic measurements were observed between the groups at the stages of observations $(p>0.05)$ (Table 4). Arterial hypotension requiring intravenous administration of vasopressor was observed in PEAF $(\mathrm{n}=2), \operatorname{PEAB}(\mathrm{n}=3)$ and FSNBB $(\mathrm{n}=1)$ patients $(\mathrm{p}>0.05)$.

Hemoglobin concentration in capillary blood measured 130.8 (10.6) g/L in PEAF, 130.9 (12) g/L in PEAB, $128(12.3) \mathrm{g} / \mathrm{L}$ in FSNBB patients at admission to the theater, and $100.9(9.0) \mathrm{g} / \mathrm{L}$, 103.4 (15.7) $\mathrm{g} / \mathrm{L}$ and 98.9 (14.0) $\mathrm{g} / \mathrm{L}$ after the major surgical stage, respectively, $(p>0.05)$. Intraoperative hemotransfusion was required for 3 patients with one patient in each group $(\mathrm{p}>0.05)$.

Although there were statistically significant differences in the hemodynamic measurements between the group their clinical role can be neglected because the mean values were within age related reference interval for the cohort of patients (Table 5).

NSAID as an additive was mostly administered for groups II and III. Paracetamol was injected for 32 out of $37(86,5 \%)$ PEAB and for 31 out of $32(97 \%)$ FSNBB patients. PEAF patients required additives in $47 \%(15$ out of 32$)(p<0.05)$ due to the use of fentanyl injections for sedation. Fentanyl infusion for sedation consisted of the medium dose of $33.5(12.5) \mathrm{mcg} / \mathrm{kg}$ in PEAF patients. There were no statistically significant differences in midazolam medium dose in PEAB and FSNBB groups measuring $1.1(0.7) \mathrm{mg} / \mathrm{kg} / \mathrm{h}$ and $1.0(0.4) \mathrm{mg} / \mathrm{kg} / \mathrm{h}$, respectively $(\mathrm{p}>0.05)$. There were no significant differences in the level of pain, agitation and sedation level, postoperative depth of sedation scored at the ICU among the groups $(p>0.05)$ (Table 6).

Table 4

Intraoperative hemodynamic findings

\begin{tabular}{|l|c|c|c|c|c|c|c|}
\hline Groups & $\begin{array}{c}\text { Hemodynamic } \\
\text { measurements }\end{array}$ & $\begin{array}{c}\text { Admission to } \\
\text { theater }\end{array}$ & $\begin{array}{c}\text { Tracheal } \\
\text { intubation }\end{array}$ & $\begin{array}{c}\text { After epidural injection } \\
\text { of local anesthetic }\end{array}$ & $\begin{array}{c}\text { Beginning of } \\
\text { surgery }\end{array}$ & $\begin{array}{c}\text { Major surgical } \\
\text { phase }\end{array}$ & $\begin{array}{c}\text { Tracheal } \\
\text { extubation }\end{array}$ \\
\hline \multirow{2}{*}{ PEAF } & MAP $(\mathrm{mmHg})$ & $71(7)$ & $69(8)$ & $62(10)$ & $59(10)$ & $54(9)$ & $57(8)$ \\
\cline { 2 - 8 } & HR beats/min. & $117(14)$ & $114(14)$ & $112(13)$ & $108(13)$ & $103(14)$ & $100(11)$ \\
\hline \multirow{2}{*}{ PEAB } & MAP $(\mathrm{mmHg})$ & $71(8)$ & $66(8)$ & $61(8)$ & $58(7)$ & $54(6)$ & $59(8)$ \\
\cline { 2 - 8 } & HR beats $/ \mathrm{min}$. & $122(14)$ & $118(14)$ & $113(12)$ & $111(13)$ & $103(15)$ & $100(14)$ \\
\hline \multirow{2}{*}{ FSNBB } & MAP $(\mathrm{mmHg})$ & $73(7)$ & $70(8)$ & $61(9)$ & $58(8)$ & $56(9)$ & $57(9)$ \\
\cline { 2 - 8 } & HR beats/min. & $121(10)$ & $118(8)$ & $114(10)$ & $111(10)$ & $107(11)$ & $101(11)$ \\
\hline
\end{tabular}

Single-factor analysis of variance; $\mathrm{p}>0.05$.

Table 5

Dynamics in hemodynamic measurements at early postoperative period

\begin{tabular}{|l|c|c|c|c|}
\hline Groups & Hemodynamic measurements & Admission to ICU & at 6 hours & Transportation to the clinical department \\
\hline \multirow{2}{*}{ PEAF } & MAP (mmHg) & $70(20)^{*}$ & $72(17)^{*}$ & $70(16)^{*}$ \\
\cline { 2 - 5 } & HR beats/min. & $111(26)^{*}$ & $110(30)$ & $115(26)$ \\
\hline \multirow{2}{*}{ PEAB } & MAP (mmHg) & $72(13)^{*}$ & $79(11)^{*}$ & $114(21)$ \\
\cline { 2 - 5 } & HR beats/min. & $116(18)^{*}$ & $116(21)$ & $78(11)^{*}$ \\
\hline \multirow{2}{*}{ FSNBB } & MAP (mmHg) & $82(15)^{*}$ & $81(12)^{*}$ & $120(15)$ \\
\cline { 2 - 5 } & HR beats/min. & $124(15)^{*}$ & $118(16)$ & \\
\hline
\end{tabular}

Single-factor analysis of variance; $* \mathrm{p}>0.05$.

Table 6

Assessment of pain intensity and sedation score

\begin{tabular}{|c|c|c|c|c|c|}
\hline \multicolumn{2}{|c|}{ Group } & Admission to ICU & After 6 hours & Transportation to clinical department & At the clinical department \\
\hline \multirow{3}{*}{ PEAF } & r-FLACC & $0.5(0.8)$ & $1(1.3)$ & $1(1.4)$ & $1.3(1.4)$ \\
\hline & Ramsay & $3.7(1.3)$ & $3.6(1.0)$ & $3.3(0.8)$ & $2.7(0.9)$ \\
\hline & Richmond & $-1.8(1.4)$ & $-1.4(1.2)$ & $-1.1(1.0)$ & $-0.1(0.7)$ \\
\hline \multirow{3}{*}{ PEAB } & r-FLACC & $0.7(1.2)$ & $1.3(1.8)$ & $1(1.5)$ & $0.7(1.3)$ \\
\hline & Ramsay & $3.9(0.6)$ & $3.4(1.0)$ & $3.3(0.8)$ & $3(0.5)$ \\
\hline & Richmond & $-2.2(1.1)$ & $-1(1.6)$ & $-0.9(1.4)$ & $-0.2(0.7)$ \\
\hline \multirow{3}{*}{ FSNBB } & r-FLACC & $1.1(1.4)$ & $1.1(1.2)$ & $0.6(1.0)$ & $0.6(1.1)$ \\
\hline & Ramsay & $3.6(1.2)$ & $3.5(1.4)$ & $3.2(0.8)$ & $2.9(0.8)$ \\
\hline & Richmond & $-1.8(1.3)$ & $-1.6(1.2)$ & $-0.8(1.1)$ & $-0.3(0.7)$ \\
\hline
\end{tabular}

Analysis of variance, $p>0.05$ 


\section{DISCUSSION}

There were no significant differences in major intraoperative variables between the groups of our series. No adverse events associated with a continuous femoral plus single-shot sciatic nerve block and prolonged epidural analgesia were recorded in $\mathrm{CP}$ pateints. Our findings indicated to the effectiveness and safety of the regional anesthesia techniques used for patients with moderate and severe $\mathrm{CP}$ treated with multi-level lower limb surgeries and were shown to be on par with the data reported in the large multicenter studies [15, 25]. Paracetamol as an additive to the regional anesthesia allowed us to avoid use of opioids providing analgetic effect comparable with PEA potentiated by microfluid fentanyl injection. Maintaining light or moderate levels of sedation in
ICU patients improved muscle spasticity and pain. Use of benzodiazepines facilitated optimal environment for the patients, physical and psychological comfort avoiding opioid related adverse effects. Shortterm apnoea in a PEAF patients was recorded as a complication that was likely to be associated with fentanyl infusion. Such serious adverse respiratory effects as opioid related respiratory depression are well known in pediatric practice being more common for $\mathrm{CP}$ patients due to severe neurological symptoms as compared to the patients without co-occuring condition [26, 27]. No complications were observed in PEAB and FSNBB patients due to minimum use of opioids that is in line with reported data from multicenter studies [13, 17, 25-27].

\section{CONCLUSION}

1. A continuous femoral plus single-shot sciatic nerve block as an analgesic component of the anesthesiological management has been shown to yield the similar effectiveness as the prolonged epidural analgesia in CP patients undergoing multilevel lower limb surgeries.

2. A continuous femoral nerve block and PEA potentiated by NSAID (paracetamol) have demonstrated better effectiveness/safety profile as compared to the use of PEA and fentanyl injection for sedation.

3. Benzodiazepines administered for children with moderate and severe $\mathrm{CP}$ at early postoperative period facilitated physical and psychological comfort presenting a safe alternative to opioids.

\section{REFERENCES}

1. Hauer J., Houtrow A.J.; Section on Hospice and Palliative Medicine, Council of Children with Disabilities. Pain Assessment and Treatment in Children with Significant Impairment of the Central Nervous System. Pediatrics, 2017, vol. 139, no. 6, pp. e20171002. DOI: 10.1542/peds.20171002 .

2. Massaro M., Pastore S., Ventura A., Barbi E. Pain in cognitively impaired children: a focus for general pediatricians. Eur. J. Pediatr., 2013, vol. 172, no. 1, pp. 9-14. DOI: 10.1007/s00431-012-1720-x

3. Paolucci S., Martinuzzi A., Scivoletto G., Smania N., Solaro C., Aprile I., Armando M., Bergamaschi R., Berra E., Berto G., Carraro E., Cella M., Gandolfi M., Masciullo M., Molinari M., Pagliano E., Pecchioli C., Roncari L., Torre M., Trabucco E., Vallies G., Zerbinati P., Tamburin S. Assessing and treating pain associated with stroke, multiple sclerosis, cerebral palsy, spinal cord injury and spasticity. Evidence and recommendations from the Italian Consensus Conference on Pain in Neurorehabilitation. Eur. J. Phys. Rehabil. Med., 2016, vol. 52, no. 6, pp. 827-840.

4. Warlow T.A., Hain R.D.W. 'Total Pain' in Children with Severe Neurological Impairment. Children (Basel), 2018, vol. 5, no. 1, pp. 13. DOI: 10.3390/ children5010013

5. Ramstad K., Jahnsen R., Skjeldal O.H., Diseth T.H. Characteristics of recurrent musculoskeletal pain in children with cerebral palsy aged 8 to 18 years. Dev. Med. Child. Neurol., 2011, vol. 53, no. 11, pp. 1013-1018. DOI: 10.1111/j.1469-8749.2011.04070.x

6. Sampson E.L., Van der Steen J.T., Pautex S., Svartzman P., Sacchi V., Van den Block L., Van den Noortgate N. European palliative care guidelines: how well do they meet the needs of people with impaired cognition? BMJ Support Palliat. Care, 2015, vol. 5, no. 3, pp. 301-305. DOI: 10.1136/ bmjspcare-2014-000813

7. Alriksson-Schmidt A., Hägglund G. Pain in children and adolescents with cerebral palsy: a population-based registry study. Acta Paediatr., 2016, vol. 105, no. 6, pp. 665-670. DOI: 10.1111/apa.13368

8. Lins L.A.B., Watkins C.J., Shore B.J. Natural History of Spastic Hip Disease. J. Pediatr. Orthop., 2019, vol. 39 , no. 5, Suppl. 1, pp. S33-S37. DOI: $10.1097 / \mathrm{BPO} .0000000000001347$

9. Larnert P., Risto O., Hägglund G., Wagner P. Hip displacement in relation to age and gross motor function in children with cerebral palsy. J. Child. Orthop., 2014, vol. 8, no. 2, pp. 129-134. DOI: 10.1007/s11832-014-0570-7

10. Hägglund G., Lauge-Pedersen H., Wagner P. Characteristics of children with hip displacement in cerebral palsy. BMC Musculoskelet. Disord., 2007, vol. 26, no. 8, pp. 101. DOI: 10.1186/1471-2474-8-101

11. Bugler K.E., Gaston M.S., Robb J.E. Hip displacement in children with cerebral palsy in Scotland: a total population study. J. Child. Orthop., 2018, vol. 12, no. 6, pp. 635-639. DOI: 10.1302/1863-2548.12.180106

12. Dohin B. The spastic hip in children and adolescents. Orthop. Traumatol. Surg. Res., 2019, vol. 105, no. 1S, pp. S133-S141. DOI: 10.1016 / j.otsr.2018.03.018

13. Lanzillotta J.A., Clark A., Starbuck E., Kean E.B., Kalarchian M. The Impact of Patient Characteristics and Postoperative Opioid Exposure on Prolonged Postoperative Opioid Use: An Integrative Review. Pain Manag. Nurs., 2018, vol. 19, no. 5, pp. 535-548. DOI: 10.1016/j.pmn.2018.07.003.

14. Verghese S.T., Hannallah R.S. Acute pain management in children. J. Pain Res., 2010, vol. 3, pp. 105-123. DOI: 10.2147/jpr.s4554

15. Ecoffey C., Lacroix F., Giaufré E., Orliaguet G., Courrèges P.; Association des Anesthésistes Réanimateurs Pédiatriques d'Expression Française (ADARPEF). Epidemiology and morbidity of regional anesthesia in children: a follow-up one-year prospective survey of the French-Language Society of Paediatric Anaesthesiologists (ADARPEF). Paediatr. Anaesth., 2010, vol. 20, no. 12, pp. 1061-1069. DOI: 10.1111/j.1460-9592.2010.03448.x

16. Shaikh S.I., Hegade G. Role of Anesthesiologist in the Management of a Child with Cerebral Palsy. Anesth. Essays Res., 2017, vol. 11, no. 3, pp. 544-549. DOI: 10.4103/0259-1162.194569 
17. Kendall M.C., Alves L.J.C., Suh E.I., McCormick Z.L., De Oliveira G.S. Regional anesthesia to ameliorate postoperative analgesia outcomes in pediatric surgical patients: an updated systematic review of randomized controlled trials. Local Reg. Anesth., 2018, vol. 11, pp. 91-109. DOI: 10.2147/ LRA.S185554

18. Diordiev A.V., Aizenberg V.L., Vinogradov A.V., Vainshtein D.P., Shagurin R.V. Anesteziia pri khirurgicheskom lechenii u bolnykh tserebralnym paralichom (obzor) [Anesthesia in surgical treatment of patients with cerebral palsy (Overview)]. Zhurnal Nevrologii i Psikhiatrii im. S.S. Korsakova, 2012, vol. 112, no. 7-2, issue 2. Detskaia Nevrologiia, pp. 41-46. (in Russian)

19. Evreinov V.V., Zhirova T.A. Lechenie boli u detei s detskim tserebralnym paralichom pri rekonstruktivnykh ili palliativnykh operatsiiakh na tazobedrennom sustave [Pain treatment in children with cerebral palsy when performing reconstructive or palliative surgeries of the hip]. Anesteziologiia i Reanimatologiia, 2019, no. 5, pp. 75-80. (in Russian)

20. Russian Federation. The Order of the RF Ministry of Health № 200n of April 1, 2016, Ob utverzhdenii pravil nadlezhashchei klinicheskoi praktiki [On the Approval of the Rules of Proper Clinical Practice]. Available at: https://base.garant.ru/71473446/\#block_3 (accessed 17.07.2019). (in Russian)

21. Fournier R., Van Gessel E., Gaggero G., Boccovi S., Forster A., Gamulin Z. Postoperative analgesia with «3-in-1» femoral nerve block after prosthetic hip surgery. Can. J. Anaesth., 1998, vol. 45, no. 1, pp. 34-38. DOI: 10.1007/BF03011989

22. Raj P.P., Parks R.I., Watson T.D., Jenkins M.T. A new single-position supine approach to sciatic-femoral nerve block. Anesth. Analg., 1975, vol. 54, no. 4, pp. 489-493. DOI: 10.1213/00000539-197507000-00020

23. Robinson B.R., Berube M., Barr J., Riker R., Gélinas C. Psychometric analysis of subjective sedation scales in critically ill adults. Crit. Care Med., 2013, vol. 41, no. 9, Suppl. 1, pp. S16-S29. DOI: 10.1097 / CCM.0b013e3182a16879

24. Malviya S., Voepel-Lewis T., Burke C., Merkel S., Tait A.R. The revised FLACC observational pain tool: improved reliability and validity for pain assessment in children with cognitive impairment. Paediatr. Anaesth., 2006, vol. 16, no. 3, pp. 258-265. DOI: 10.1111/j.1460-9592.2005.01773.x

25. Polaner D.M., Taenzer A.H., Walker B.J., Bosenberg A., Krane E.J., Suresh S., Wolf C., Martin L.D. Pediatric Regional Anesthesia Network (PRAN): a multi-institutional study of the use and incidence of complications of pediatric regional anesthesia. Anesth. Analg., 2012, vol. 115, no. 6, pp. 1353-1364. DOI: 10.1213/ANE.0b013e31825d9f4b

26. Mizuno J., Morita S., Hanaue N., Hanaoka K., Yokoyama T. [Intravenous patient-controlled analgesia (IV-PCA) for relief of postoperative pain]. Masui, 2011, vol. 60, no. 8, pp. 908-912. (in Japanese)

27. Kabara S., Kagawa T., Ikejima N., Takatsuji S., Sueda A. [Side Effects of Continuous Fentanyl Infusion for Postoperative Pain Relief in Children]. Masui, 2015, vol. 64, no. 8, pp. 799-803. (in Japanese)

Received: 25.03 .2020

\section{Information about the authors:}

1. Vadim V. Evreinov, M.D.,

Ilizarov National Medical Research Centre for Orthopaedics and Traumatology, Kurgan, Russian Federation, Email: Evreinov2020@mail.ru

2. Tatyana A. Zhirova, M.D., Ph.D., V.D. Chaklin Ural Institute of Traumatology and Orthopedics, Ekaterinburg, Russian Federation 